\title{
Correlation of "Watch" Antibiotic Consumption with a Gram-negative Bacteria Resistance: Analysis at a Country Level
}

\author{
"Izlem" Grubu Antibiyotik Tüketiminin Gram-olumsuz Bakteri Direnci ile Ilişkisi: \\ Ülke Düzeyinde Analiz
}

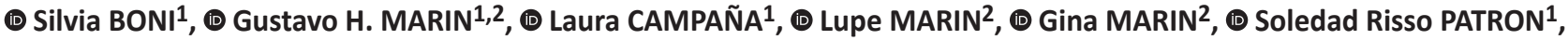

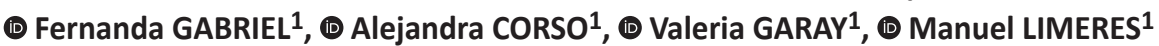 \\ ${ }^{1}$ ANMAT - National Administration of Drugs, Food and Technology of Argentina (National Ministry of Health), Buenos Aires, Argentina \\ 2 UNLP - National University of La Plata-CONICET, Faculty of Medical Science, Buenos Aires, Argentina
}

\section{Abstract}

Introduction: Bacterial antimicrobial resistance (AMR) to the antibiotics (ATB) has severe consequences for human health. The excess ATB consumption is one of the main causes of AMR. One of the World Health Organizations main objective in AMR control strategy is to limit the ATB irrational use, that is why, it proposed to classify the ATB in three groups: "Access", "Watch", and "Reserve", being the latter two preserved for certain situations. The present work aims to know the level of ATB consumption and its correlation with the Gram-negative resistance in Argentina.

Materials and Methods: Gram-negative bacteria resistance to "watch" the ATB groups (cephalosporins/carbapenem/fluoroquinolones) were explored for Escherichia coli, Klebsiella pneumoniae, and Pseudomonas aeruginosa. Antibiotic consumption was expressed by the defined daily dose/1000 inhabitants for each ATB for one year period (2018). Resistance/consumption ratio was obtained by calculating the "R" for each region of the country, comparing them with the other countries.

Results: E. coli resistance to $3^{\text {rd }}$ generation cephalosporines was $8.68 \%$ and $16.51 \%$ in urine (U) and blood (B) samples, respectively, while to carbapenems was $0.08 \%(\mathrm{U})$ and $0.36 \%(\mathrm{~B})$. Resistance of $K$. pneumoniae to $3 \mathrm{GC}$ was $39.78 \%(\mathrm{U})$ and $52.45 \%(\mathrm{~B})$ while to carbapenem was $9.03 \%$ (U) and $17.46 \%$ (B). P. aeruginosa resistance to fluoroquinolone and to carbapenems was 29.7\% (U)/26.4\% (B) and 17.7\% (U)/19.9\% (B), respectively. The resistance/consumption ratio was heterogenous within the country. Most of the populated areas patterns had similarities with the one observed in the less developed countries (mild-high resistance/mild-high consumption), while the ratio found in less densely populated areas, mimicked countries with the most rational use of ATB.

Conclusion: In Argentina, Gram-negative bacteria showed overall high/mild resistance levels against the "Watch" ATB groups, with a largely variations among each region.

Keywords: Gram-negative, cephalosporine, carbapenems, fluoroquinolones, resistance, consumption

\section{Öz}

Giriş: Antibiyotiklere (ATB) karşı bakteri direncinin (AMR) insan sağlığı için ciddi sonuçları vardır. Antibiyotik tüketimindeki fazlalık, AMR'nin ana nedenlerinden biridir. Dünya Sağlık Örgütü'nün (DSÖ) AMR kontrol stratejisindeki temel amaçlarından biri, ATB'nin irrasyonel kullanımını sınırlamaktır, bu nedenle DSÖ ATB'leri "Erişim", "İzlem" ve "Rezerv" grubu ATB'ler olmak üzere üç grupta sınıflandırmayı önermiştir. Son iki ATB grubu belirli durumlar için saklanmalıdır. Bu çalışma, Arjantin'deki ATB tüketiminin seviyesini ve bunun Gram-olumsuzlardaki dirençle ilişkisini bilerlemeyi amaçlamaktadır.

Gereç ve Yöntem: Escherichia coli, Klebsiella pneumoniae ve Pseudomonas aeruginosa için "Izlem" grubu ATB'lere karşı (sefalosporinler/ karbapenem/florokinolonlar) Gram-olumsuz bakteri direnci araştırıldı. Antibiyotik tüketimi, bir yıllık süre boyunca (2018) her ATB için tanımlanmış günlük doz/1000 kişi ile ifade edildi. Direnç/tüketim oranı, ülkenin her bölgesi için "R" hesaplanarak ve diğer ülkelerle karşılaştırılarak elde edildi.

Cite this article as: Boni S, H. Marin G, Campaña L, Marin L, Marin G, Patron SR, Gabriel F, Corso A, Garay V, Limeres M. Correlation of "Watch" Antibiotic Consumption with a Gram-negative Bacteria Resistance: Analysis at a Country Level. Mediterr J Infect Microb Antimicrob. 2021;10:67. 
Bulgular: E. coli'nin 3. kuşak sefalosporinlere karşı direnci idrar (U) ve kan (B) örneklerinde sırasıyla \%8,68 ve \%16,51; karbapenemlere karşı direnci ise \%0,08 (U) ve \%0,36 (B) idi. K. pneumoniae'nin 3. kuşak sefalosporinlere karşı direnci \%39,78 (U) ve \%52,45 (B) iken karbapenem direnci \%9,03 (U) ve \%17,46 (B) idi. P. aeruginosa'nın florokinolon ve karbapenemlere karşı direnci sırasıyla \%29,7 (U)/\%26,4 (B) ve \%17,7 (U)/\%19,9 (B) idi. Direnç/ tüketim oranı ülke içinde heterojendi. Nüfusun yoğun olduğu alanların çoğu, daha az gelişmiş ülkelerde gözlenenle benzerlikler gösterirken (hafifyüksek direnç/hafif-yüksek tüketim), nüfusun daha az yoğun olduğu bölgelerde bulunan oran, ATB'nin en rasyonel kullanımına sahip ülkelerdekine benzerdi.

Sonuç: Arjantin'de Gram-olumsuz bakteriler, bölgeler arasında büyük farklılıklarla birlikte, "İzlem” grubu ATB'lere karşı genel olarak yüksek/hafif direnç seviyelerine sahipti.

Anahtar Kelimeler: Gram-olumsuz, sefalosporin, karbapenemler, florokinolonlar, direnç, tüketim

\section{Introduction}

As new antibiotics (ATB) are designed, bacteria develop more sophisticated and complex resistance mechanisms, in a kind of irrational contest whose finish line ends with a severe decline of the health and environment status ${ }^{[1]}$.

There is a large amount of evidence about the link between ATB use and its' resistance development ${ }^{[2]}$. That is why, one of the World Health Organization (WHO) strategies to avoid the irrational use of ATB was to classify the antimicrobials in three groups "Access", "Watch", and "Reserve", proposing to limit the consumption of the last two groups only to special situations $^{[3]}$.

Enterobacteriaceae (Escherichia coli, Klebsiella pneumoniae) and Pseudomonas aeruginosa are the major cause of bloodstream and urinary tract infections, either in the ambulatory or inhospital population ${ }^{[4]}$. Antibiotic antimicrobial resistance (AMR) developed by these microorganisms, expresses the ability to grow in the presence of the drugs designed to inhibit them ${ }^{[5]}$. The most common resistance mechanisms to "Watch" ATB group like $3^{\text {rd }}$ generation cephalosporines or carbapenems is the synthesis of beta-lactamase enzymes ${ }^{[6]}$; while the resistance to fluoroquinolones is associated to DNA gyrase (topoisomerase II) enzyme mutations $(g y r A, g y r B)^{[7]}$.

In the recent years, the increased detection and spread of bacterial resistance in Latin America and the Caribbean, illustrates the seriousness of the AMR problem and the imperative need to make countries aware and engage to adopt the local policies to regulate ATB consumption ${ }^{[8]}$.

The aim of this study is to analyze "Watch" ATB consumption and Gram-negative bacteria resistance to reduce the AMR in Argentina.

\section{Materials and Methods}

Type of study: It is a descriptive, retrospective study to establish the quality/quantity of ATB consumption (Drug Utilization
Research) and bacterial resistance profiles in Argentina during the period January $1^{\text {st }}$ to December $31^{\text {st }}, 2018$.

Bacterial resistance detection process: Gram-negative bacteria (Escherichia coli, Klebsiella pneumoniae, Pseudomonas aeruginosa) urine (U) and blood (B) samples were obtained from WHONET sentinel health Institutions (outpatients and hospitals) from every region in Argentina ${ }^{[9]}$. Bacteria were identified by using Microgen ${ }^{\circledast}$ Brand Biochemical Test Identification Kits. Their resistance patterns were obtained using the Kirby-Bauer disk diffusion method, categorizing each isolate microorganism as sensitive, intermediate, or resistant to each specific antibiotic. High resistance was defined as $>50 \%$ specimen resistance to a particular antibiotic; intermediate resistance was categorized as 20-50\% resistance level and low resistance was considered when $<20 \%$ bacterial resistance was detected ${ }^{[10]}$. The boxes were incubated for at least 18 hours at $37{ }^{\circ} \mathrm{C}$ before taking the readings. Although several ATB were tested, this study focused in "Watch" ATB groups. Samples were processed following the standardized procedures by the Clinical and Laboratory Standards Institute. After performing a bacterial culture and laboratory test, data of resistance was validated by the Malbran Institute which is a member of the International Reference Laboratory for the WHONET Network of the $\mathrm{WHO}^{[9]}$.

ATB consumption data was obtained from sales of $3^{\text {rd }}$ generation cephalosporine, fluoroquinolones, and carbapenem products declared by the pharmaceutical industry in 23 Argentine provinces and the Autonomous City of Buenos Aires (CABA). ATB information was collected considering the type of ATB according to the anatomical therapeutic chemical classification. Consumption was calculated as defined daily doses (DDD) (WHO technical metrics for drug consumption which expresses the daily DDD for its main indication in adults) ${ }^{[11]}$. It was considered the geographical area in which consumption was registered, and the level of resistance for the different ATB in each region, global consumption in the country was expressed in DDD per 1,000 inhabitants per day (DHD). The calculation was made for each medicine and year 
of the period analyzed, according to the formula of DHD given below:

$\mathrm{DHD}=\frac{\text { Overall grams consumed of each drug } \times 1000 \text { inhabitants }}{\mathrm{DDD} \times \mathrm{N}^{\circ} \text { inhabitants } \times 365 \text { days }}$

DHD was calculated by computerized methods using a program designed for this purpose.

Population exposed (PE) to the drugs. It was calculated for each active principle in the period analyzed, according to the formula:

$\mathrm{PE}=\frac{\mathrm{DHD} \times \mathrm{N}^{\mathrm{o}} \text { of Inhabitants }}{1000}$

- DDD. Technical unit of measurement of the drug consumption known as a $D D D$, and which expresses the daily dose of a drug for its main indication in adults.

- DHD. It expresses the number of inhabitants of every 1000 that consume a DDD every day of a certain drug.

- Consumption. Quantity of medicines, in any of their forms of presentation, sold by the provincial warehouses to the health units for their use.

- Exposed population (PE). Number of patients exposed to a certain medicine. It is calculated from the DHD.

\section{Data Analysis}

Consumption was analyzed considering to the DDD/DHD WHO formula. Gram-negative bacteria resistance data was expressed in percentage of the pathogen resistance to each antibiotic group using WHONET 5.6 software. After recording each resistance values, these levels of resistance were compared with an antibiotic consumption detected.

Results were grouped and stratified by the federal states and regions due to their different historical, geographical, social, economic, and sanitary situations. Additionally, results obtained for each Argentinian regions were analyzed in relation to the previous published information from other countries extracted from WHO, the European Center for Disease Prevention and Control and the European Antibiotic Resistance Surveillance Network annual reports ${ }^{[12-14]}$.

For the statistical analysis of consumption data, and consumption/resistance ratio, it was used the open access software for statistical computing and graphics " $\mathrm{R}$," version 4.0.0, with its default packages, tidy verse, Agricole package, and ggplot for the development of the graphs.

\section{Ethical Statement}

All the information was extracted from the secondary database in which it was not possible to identify the people involved. For this reason, the anonymity of the data was always guaranteed in all the stage of the study. Research protocol № 011/17 was approved by the CIC Scientific Research Committee.

\section{Results}

\section{Antibiotic Consumption}

The consumption of "Watch" ATBs analysis was limited to the main groups: $3^{\text {rd }}$ generation cephalosporines, carbapenems, and fluoroquinolones groups.

Concerning the consumption of cephems beta-lactams, the consumption level was variable among the $3^{\text {rd }}$ generation of cephalosporines (Table 1).

Among carbapenem group, levels of consumption of imipenem and meropenem are shown in Table 2.

Regarding the fluoroquinolone group, ciprofloxacin was the most consumed drug, followed by levofloxacin (Table 3).

\section{Bacterial Resistance Data}

Bacterial sensibility/resistance profile was performed according to the method described. Since Argentina is divided into the federal states that confirm several different regions; although data is shown globally, it was also grouped

Table 1. Consumption of cephalosporins

\begin{tabular}{l|l}
\hline Type of cephalosporinses & $\mathrm{CL}$ \\
\hline Cefixime $3^{\circ} \mathrm{G}$ & 0.0435 \\
\hline Cefotaxime $3^{\circ} \mathrm{G}$ & 0.0052 \\
\hline Ceftazidime $3^{\circ} \mathrm{G}$ & 0.0053 \\
\hline Ceftazidime/avibactam $3^{\circ} \mathrm{G}$ & 0.0024 \\
\hline Ceftriaxone $3^{\circ} \mathrm{G}$ & 0.015 \\
\hline
\end{tabular}

CL: Consumption level express consumption during 2018 measured as defined daily dose by each 1000 inhabitants

Table 2. Consumption of carbapenem

\begin{tabular}{l|l}
\hline Type of carbapenem & $\mathrm{CL}$ \\
\hline Ertapenem & 0.001275 \\
\hline Imipenem & 0.00016 \\
\hline Meropenem & 0.00021 \\
\hline $\begin{array}{l}\text { CL: Consumption level express consumption during } 2018 \text { measured as defined daily } \\
\text { dose by each 1000 inhabitants }\end{array}$
\end{tabular}

Table 3. Consumption of fluoroquinolone

\begin{tabular}{l|l}
\hline Type of fluoroquinolone & $\mathrm{CL}$ \\
\hline Ciprofloxacin & 0.7838 \\
\hline Levofloxacin & 0.51 \\
\hline Moxifloxacin & 0.0065 \\
\hline Norfloxacin & 0.1410
\end{tabular}

CL: Consumption level express consumption during 2018 measured as defined daily dose by each 1000 inhabitants 
according to the areas. Resistance of Gram-negative bacteria were limited to those germs with the highest prevalence of infections in the country which are $E$. coli, $K$. pneumoniae, $P$. aeruginosa.

\section{Escherichia coli}

E. coli resistance to $3^{\text {rd }}$ generation cephalosporines was $8.68 \%$ in U samples and $16.51 \%$ B samples, while its resistance to carbapenems was $0.08 \%(\mathrm{U})$ and $0.36 \%(\mathrm{~B})$, respectively (Table 4).

\section{Klebsiella pneumoniae}

Resistance of $K$. pneumoniae was tested against beta-lactams belonging to the $3^{\text {rd }}$ generation cephalosporine group and carbapenems. Concerning $3 \mathrm{GC}$, it was detected an overall level of resistance of $39.78 \%$ in $U$ samples and $52.45 \%$ B samples; while for carbapenem resistance levels were 9.03\% (U) and $17.46 \%$ (B), with a wide fluctuation according to the country's geographical area where the samples were obtained (Table 5).

\section{Pseudomonas aeruginosa}

$P$. aeruginosa resistance was tested against the carbapenem and fluoroquinolones ATB "Watch" groups. The global level of resistance obtained to fluoroquinolone was 29.7\% (U)/26.4\% (B) and to carbapenems was $17.7 \%(\mathrm{U}) / 19.9 \%(\mathrm{~B})$, respectively. However, differences were seen among each country region (Table 6).

Table 4. Escherichia coli resistance profile

\begin{tabular}{|c|c|c|c|c|c|c|c|c|c|c|c|c|c|c|c|c|c|c|c|}
\hline \multirow{2}{*}{$\begin{array}{l}\text { Mechanism of } \\
\text { resistance }\end{array}$} & \multirow[t]{2}{*}{$S$} & \multicolumn{3}{|c|}{$\begin{array}{l}\text { Capital City } \\
\text { (CABA) }\end{array}$} & \multicolumn{3}{|c|}{$\begin{array}{l}\text { Buenos Aires } \\
\text { (BUE) }\end{array}$} & \multicolumn{3}{|c|}{$\begin{array}{l}\text { Center } \\
(\text { CEN) }\end{array}$} & \multicolumn{3}{|c|}{$\begin{array}{l}\text { Cuyo Region } \\
\text { (CUYO) }\end{array}$} & \multicolumn{3}{|c|}{$\begin{array}{l}\text { North } \\
\text { (NOR) }\end{array}$} & \multicolumn{3}{|c|}{$\begin{array}{l}\text { Patagonia } \\
\text { (PAT) }\end{array}$} \\
\hline & & I & NRI & $\%$ & I & NRI & $\%$ & I & NRI & $\%$ & I & NRI & \begin{tabular}{|l|}
$\%$ \\
\end{tabular} & I & $\%$ & NRI & I & NRI & $\%$ \\
\hline $\begin{array}{l}\text { Resistance } \\
\text { to } 3 \mathrm{G} \\
\text { cephalosporins }\end{array}$ & $B$ & 514 & 102 & 19.8 & 614 & 120 & 19.5 & 415 & 53 & 12.8 & 214 & 30 & 14.0 & 305 & 22.3 & 68 & 262 & 28 & 10.7 \\
\hline $\begin{array}{l}\text { Carbapenemase } \\
\text { production }\end{array}$ & U & 6715 & 16 & 0.2 & 9545 & 5 & 0.1 & 7483 & 3 & 0.0 & 4045 & 3 & 0.1 & 5871 & 0.0 & 2 & 6678 & 4 & 0.1 \\
\hline
\end{tabular}

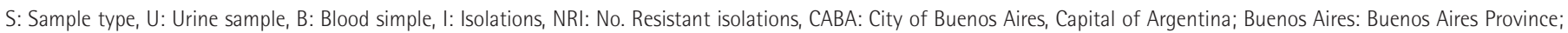

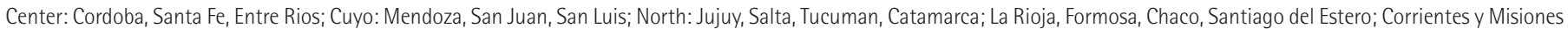

Table 5. Klebsiella pneumoniae resistance profile

\begin{tabular}{|c|c|c|c|c|c|c|c|c|c|c|c|c|c|c|c|c|c|c|c|}
\hline \multirow{2}{*}{$\begin{array}{l}\text { Mechanism of } \\
\text { resistance }\end{array}$} & \multirow[t]{2}{*}{$S$} & \multicolumn{3}{|c|}{$\begin{array}{l}\text { Capital City } \\
\text { (CABA) }\end{array}$} & \multicolumn{3}{|c|}{$\begin{array}{l}\text { Buenos Aires } \\
\text { (BUE) }\end{array}$} & \multicolumn{3}{|c|}{$\begin{array}{l}\text { Center } \\
\text { (CEN) }\end{array}$} & \multicolumn{3}{|c|}{$\begin{array}{l}\text { Cuyo Region } \\
\text { (CUYO) }\end{array}$} & \multicolumn{3}{|c|}{$\begin{array}{l}\text { North } \\
\text { (NOR) }\end{array}$} & \multicolumn{3}{|c|}{$\begin{array}{l}\text { Patagonia } \\
\text { (PAT) }\end{array}$} \\
\hline & & I & NRI & $\%$ & I & NRI & $\%$ & I & NRI & $\%$ & I & NRI & $\%$ & I & $\%$ & NRI & I & NRI & $\%$ \\
\hline \multirow{2}{*}{$\begin{array}{l}\text { Resistance to } 3 \mathrm{G} \\
\text { cephalosporins }\end{array}$} & U & 1159 & 577 & 49.8 & 891 & 393 & 44.1 & 890 & 356 & 40.0 & 470 & 132 & 28.1 & 825 & 373 & 45.2 & 467 & 147 & 31.5 \\
\hline & B & 427 & 272 & 63.7 & 397 & 250 & 63.0 & 254 & 143 & 56.3 & 154 & 51 & 33.1 & 206 & 113 & 54.9 & 103 & 45 & 43.7 \\
\hline \multirow{2}{*}{$\begin{array}{l}\text { Carbapenemase } \\
\text { production }\end{array}$} & U & 1159 & 187 & 16.1 & 891 & 84 & 9.4 & 890 & 98 & 11.0 & 470 & 23 & 4.9 & 825 & 49 & 5.9 & 467 & 32 & 6.9 \\
\hline & B & 427 & 116 & 27.2 & 397 & 101 & 25.4 & 254 & 48 & 18.9 & 154 & 17 & 11.0 & 206 & 18 & 8.7 & 103 & 14 & 13.6 \\
\hline
\end{tabular}

S: Sample type, U: Urine sample, B: Blood simple, I: Isolations, NRI: No. Resistant isolations, CABA: City of Buenos Aires, Capital of Argentina; Buenos Aires: Buenos Aires Province;

Center: Cordoba, Santa Fe, Entre Rios; Cuyo: Mendoza, San Juan, San Luis; North: Jujuy, Salta, Tucuman, Catamarca; La Rioja, Formosa, Chaco, Santiago del Estero; Corrientes y Misiones

Table 6. Pseudomonas aeruginosa resistance profile

\begin{tabular}{|c|c|c|c|c|c|c|c|c|c|c|c|c|c|c|c|c|c|c|c|}
\hline \multirow[t]{2}{*}{ Type of resistance } & \multirow[t]{2}{*}{ S } & \multicolumn{3}{|c|}{$\begin{array}{l}\text { Capital City } \\
\text { (CABA) }\end{array}$} & \multicolumn{3}{|c|}{$\begin{array}{l}\text { Buenos Aires } \\
\text { (BUE) }\end{array}$} & \multicolumn{3}{|c|}{$\begin{array}{l}\text { Center } \\
\text { (CEN) }\end{array}$} & \multicolumn{3}{|c|}{$\begin{array}{l}\text { Cuyo Region } \\
\text { (CUYO) }\end{array}$} & \multicolumn{3}{|c|}{$\begin{array}{l}\text { North } \\
\text { (NOR) }\end{array}$} & \multicolumn{3}{|c|}{$\begin{array}{l}\text { Patagonia } \\
\text { (PAT) }\end{array}$} \\
\hline & & I & NRI & $\%$ & I & NRI & $\%$ & I & NRI & $\%$ & I & NRI & $\%$ & I & $\%$ & NRI & I & NRI & $\%$ \\
\hline $\begin{array}{l}\text { Resistance to } \\
\text { fluoroquinolone }\end{array}$ & B & 154 & 59 & 38.3 & 145 & 43 & 29.7 & 53 & 14 & 26.4 & 42 & 9 & 21.4 & 87 & 18 & 20,7 & 41 & 9 & 22.0 \\
\hline $\begin{array}{l}\text { Resistance to } \\
\text { carbapenem }\end{array}$ & U & 336 & 83 & 24.7 & 292 & 50 & 17.1 & 192 & 33 & 17.2 & 120 & 15 & 12.5 & 162 & 18 & 11,1 & 130 & 31 & 23.8 \\
\hline
\end{tabular}

S: Sample type, U: Urine sample, B: Blood sample, I: Isolations, NRI: No. Resistant isolations, CABA: Capital City of Buenos Aires, Capital of Argentina; BUE-Buenos Aires: Buenos Aires Province; CEN-Center: Cordoba, Santa Fe, Entre Rios; CUYO-CuyoRegion: Mendoza, San Juan, San Luis; NOR-North: Jujuy, Salta, Tucuman, Catamarca; La Rioja, Formosa, Chaco, Santiago del Estero; Corrientes y Misiones 


\section{Resistance/Consumption Ratio}

The resistance/consumption ratio of Gram-negative bacteria to "Watch" ATB group was heterogenous among the different areas within the country. Most of the populated areas had patterns like those observed in the less developed countries (mild-high resistance/mild-high consumption), while the ratio found in less densely populated areas, mimicked countries with the most rational use of ATB (mild-low resistance/mild-low consumption).

For E. coli, $3^{\text {rd }}$ generation cephalosporins have a relatively low consumption throughout Argentina, although the level of resistance of E. coli was high in the areas of CABA, Central and Cuyo (Like Greece, Hungary, or Romania), and certainly lower than the other countries such as Italy (28.7\%), Slovakia (30.1\%), Bolivia (33.9\%), Cyprus (37.1\%), or Bulgaria (38.7\%) (Figure 1a) ${ }^{[21]}$.

Regarding the resistance/consumption ratio of $E$. coli to carbapenem, we observed that data was heterogeneous among the regions, with a resistance/consumption ratio still low for regions such as Patagonia, and high in the rest of Argentina (Figure 1b), with extremes such as the region of CABA/ Patagonia (1.2/0.037). If these results are compared with a data reported by other countries, it could be noted that the most populated regions of Argentina had similar situations that the one reported by Greece, Cyprus, Bulgaria, or Peru, while less populated regions like Patagonia had similarities with Norway, Italy, or Finland (Figure 1b).

In Klebsiella pneumoniae, the resistance/consumption ratio demonstrated interesting data, since while consumption of $3^{\text {rd }}$ generation cephalosporins was mild/low in all regions, it was detected a high resistance of this germ to this beta-lactams, a situation that was only observed in the European countries such as Italy or Poland (Figure 2a).

On the other hand, resistance of $K$. pneumoniae to Carbapenem and the level of consumption of this antibiotic were both high in Buenos Aires and the Central Region of Argentina (like epidemiological situation reported by Bulgaria), but there was still low in Patagonia, as situation seen in Spain, Belgium, or Denmark (Figure 2b).

Resistance/consumption ratio of Klebsiella pneumoniae to fluoroquinolones was high in CABA (like that of Bulgaria or Slovakia), but mild in all the other regions, as seen in countries like to Brazil, Romania, Greece, and Italy). None of the regions in Argentina resembled the low relationship shown by the UK, France, Denmark, or Spain (Figure 2c).

Results obtained from the Pseudomonas aeruginosa demonstrated that its resistance/consumption ratio to carbapenem was high in CABA (like the data reported by Greece or Czech Republic); but low in Patagonia, where resistance profile and carbapenem consumption levels were as low as the one reported by the Scandinavian countries (Figure 3a).

The resistance/consumption relationship for fluoroquinolones was moderate in all regions (like that reported by the European Community in general), although in the Capital region (CABA) it was significantly higher than the rest of the country (Like that found in the countries like Bulgaria or Greece) (Figure 3b).

\section{Discussion}

Bacterial resistance is a global dilemma potentiated by the human behavior. Many scientific groups believe that the solution to this problem is the development of the new drugs with the ability to escape the resistance mechanism opposed by the bacteria. However, these measures will only postpone by a truly and definitive solution, which is related to the tight control the irrational usage of the current ATBs ${ }^{[15]}$.
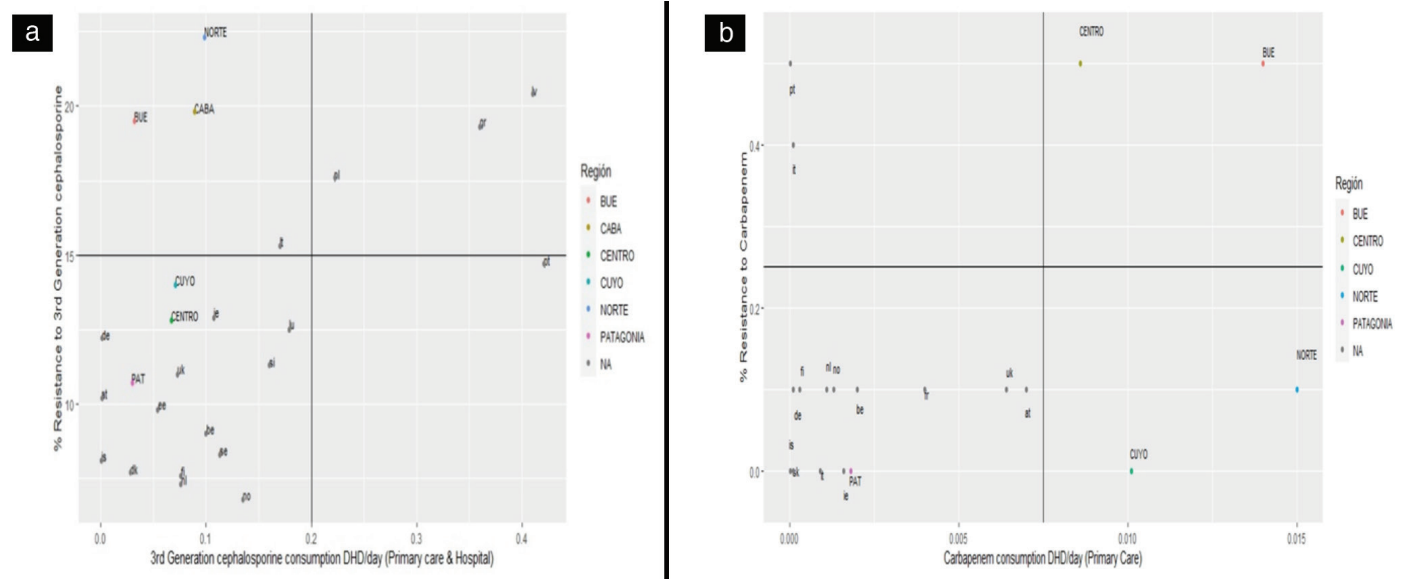

Figure 1. Comparison between consumption of $3^{\text {rd }}$ generation cephalosporins/carbapenem and resistance of $E$. coli to these antibiotics. a) $3^{\text {rd }}$ generation cephalosporins and E. coli resistance. b) Carbapenem and E. coli resistance

Note: Countries are named with their Official Country Code ${ }^{[21]}$ 

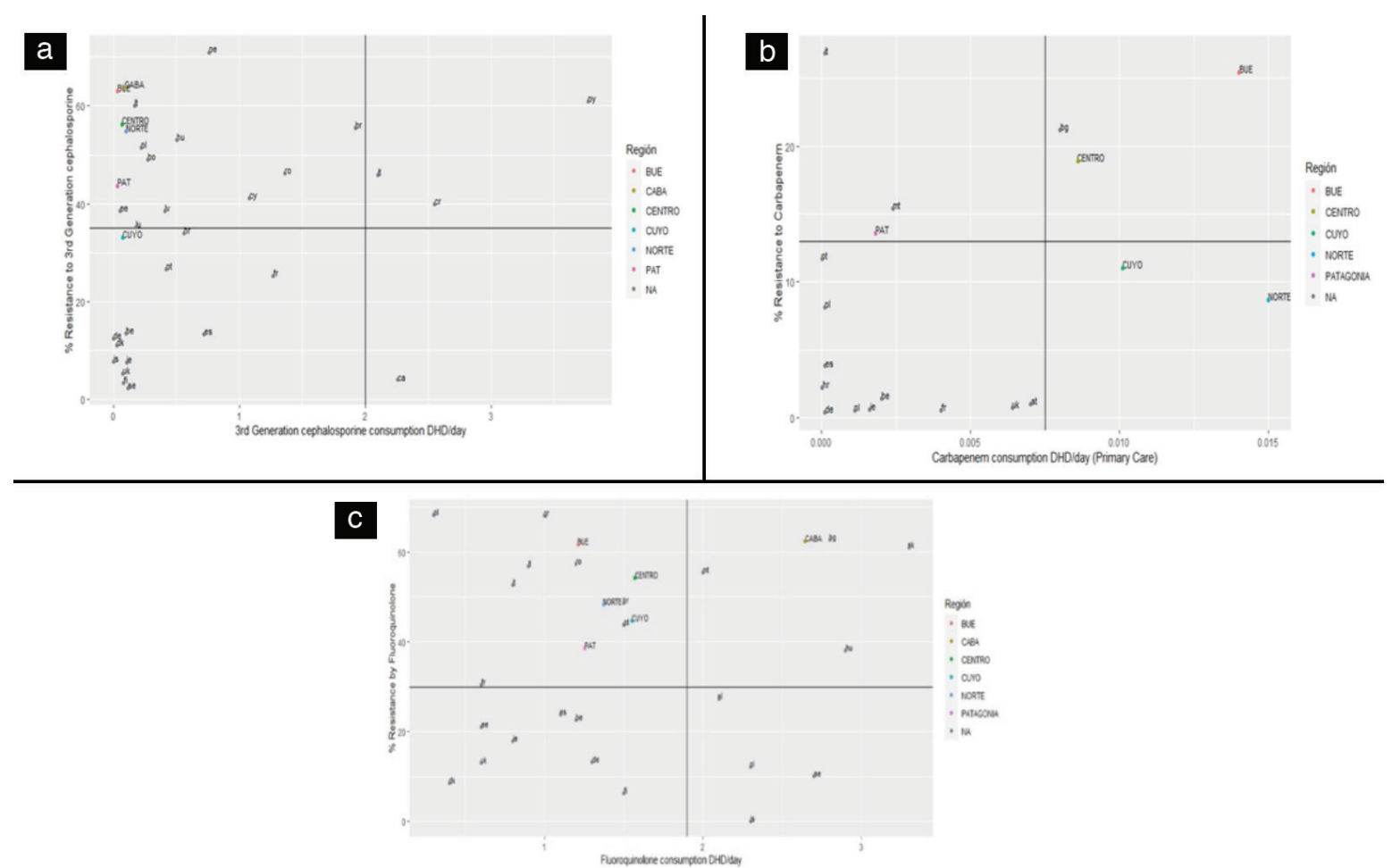

Figure 2. Comparison between consumption of $3^{\text {rd }}$ generation cephalosporins/carbapenem/fluoroquinolones and resistance of $K$. pneumoniae. a) $3^{\text {rd }}$ generation cephalosporins and $K$. pneumoniae resistance. B) Carbapenem and $K$. pneumoniae resistance. c) Fluoroquinolone and $K$. pneumoniae resistance

Note: Countries are named with their Official Country Code ${ }^{[21]}$
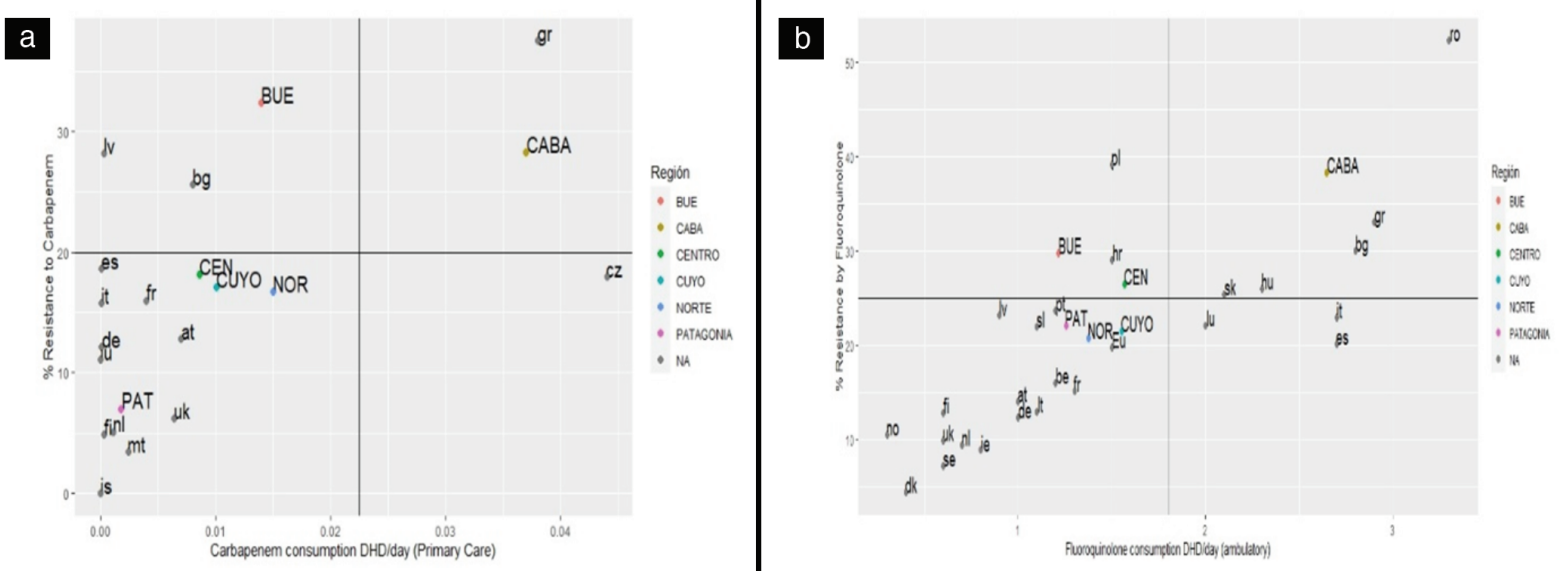

Figure 3. Comparison between the consumption of carbapenem/fluoroquinolones and resistance of $P$. aeruginosa to these antibiotics. a) Carbapenem and $P$. aeruginosa resistance. b) Fluoroquinolones and $P$. aeruginosa resistance

Note: Countries are named with their Official Country Code ${ }^{[21]}$

Hence, ATBs usage patterns are required to understand the resistance levels, and to clarify the role of ATBs consumption in preventing the spread of resistance among pathogens ${ }^{[16-18]}$.

Because of this reason, WHO proposed Aware antimicrobial classification that beware about the use of certain ATB ("Watch" and "Reserve" groups) recommending them only for the certain situations. Many efforts were made by the several countries towards a strict control of ATB usage from "Reserve" group; but the data is still limited concerning "Watch" antimicrobials ${ }^{[19]}$. This work explored the consumption at a country level of three "Watch" ATB groups ( $3^{\text {rd }}$ generation cephalosporin, carbapenem, and fluoroquinolone groups). 
Concerning Gram-negative bacterial resistance in the B samples, our study detected that for $E$. coli, the level of resistance was mild (16\%) for 3 GC and low $(<1 \%)$ for carbapenems, while resistance of $K$. pneumoniae to $3 \mathrm{GC}$ was high (52.45\%) and mild to carbapenem (17.46\%). Regarding P. aeruginosa resistance to fluoroquinolone and to carbapenem was $26.4 \%$ and $19.9 \%$, respectively. From this data exist a wide scenario of resistance levels in Argentina.

The resistance/consumption ratio detected for Gramnegative bacteria to "Watch" ATB groups studied, was also highly heterogeneous among the different areas within the country. From the results obtained, it could be said that global resistance/consumption ratio in Argentina is still considered in mild level when compared with the other countries. However, this average level does not reflect the situation of all regions that constitutes the countries territory. Certain regions of Argentina like CABA resembles some eastern European countries in relation to their high bacterial resistance due to their indiscriminate use of the ATB; while other regions like Patagonia, resemble most developed countries with a totally opposite reality.

The analysis carried out from the level of consumption of the ATB "Watch" groups and the Gram-negative bacterial resistance to these drugs; Argentina demonstrated the existence of a heterogeneous pattern. These different scenarios present in a single territory should lead us to question the global results that countries usually report, since they express an average of their multiple realities. Local realities must be taken into account to formulate the focal health policies for the control of $\mathrm{AMR}^{[19,20]}$.

The study demonstrated the correlation between the antimicrobial consumption and bacterial resistance to them at the global level of a country. The element that makes this study interesting for researchers is the disparity of the data found among the different regions of the country, showing that global data may hide the local realities. Paradoxically, the greatest limitation of the study is this heterogeneity since it makes the global country data arguable. Another limitation of the study is that it does not discriminating between hospital consumption and outpatient consumption (the study took the global consumption of the country).

\section{Conclusion}

The analysis performed about the consumption of "Watch" ATB groups $\left(3^{\text {rd }}\right.$ generation cephalosporin, carbapenem, and fluoroquinolone), and the degree of Gram-negative (E. coli, K. pneumonia and $P$. aeruginosa) bacterial resistance against these drugs; demonstrated that Argentina has a global mild resistance/ consumption ratio, but with a heterogeneous pattern among the different regions that compose the countries territory. Local realities must be considered to raise the focal health policies for AMR control.

\section{Ethics}

Ethics Committee Approval: Research protocol № 011/17 was approved by the CIC Scientific Research Committee.

Informed Consent: Retrospective study.

Peer-review: Externally and internally peer-reviewed.

\section{Authorship Contributions}

Surgical and Medical Practices: S.B., Concept: S.B., Design: G.H.M., Data Collection or Processing: L.M., F.G., A.C., V.G., Analysis or Interpretation: G.H.M., L.C., G.M., S.R.P., Literature Search: G.H.M., Writing: G.H.M., V.G., M.L.

Conflict of Interest: No conflict of interest was declared by the authors.

Financial Disclosure: This study was supported by the ANMAT (Argentine Regulaty Agency and National University of La Plata).

\section{References}

1. EMA. Reflection paper on antimicrobial resistance in the environment: considerations for current and future risk assessment of veterinary medicinal products EMA/CVMP/ERA/632109/20, 2014. Last Accessed Date: 06.10.2021. Available from: https://www.ema.europa.eu/ en/ documents/scientific-guideline/reflection-paper-antimicrobial-resistanceenvironment -considerations-current-future-risk-assessment_en.pdf

2. Bell BG, Schellevis $F$, Stobberingh $E$, Goossens $H$, Pringle M. A systematic review and meta-analysis of the effects of antibiotic consumption on antibiotic resistance. BMC Infect Dis. 2014;14:13.

3. World Health Organization (WHO). The 2019 WHO AWaRe classification of antibiotics for evaluation and monitoring of use. World Health Organization. Geneva 2019. Last Accessed Date: 6 October 2021. Available from: https:// apps.who.int/iris/handle/10665/327957

4. WHO priority pathogens list for R\&D of new antibiotics. 2017. Last Accessed Date: 06.10.2021. Available from: https://www.who.int/news/item/2702-2017-who-publishes-list-of-bacteria-for-which-new-antibiotics-areurgently-needed

5. De Oliveira DMP, Forde BM, Kidd TJ, Harris PNA, Schembri MA, Beatson SA, Paterson DL, Walker MJ. Antimicrobial Resistance in ESKAPE Pathogens. Clin Microbiol Rev. 2020;33:e00181-19.

6. Breijyeh Z, Jubeh B, Karaman R. Resistance of gram-negative bacteria to current antibacterial agents and approaches to resolve it. Molecules. 2020;25:1340.

7. Redgrave LS, Sutton SB, Webber MA, Piddock $\sqcup$. Fluoroquinolone resistance: mechanisms, impact on bacteria, and role in evolutionary success. Trends Microbiol. 2014;22:438-45.

8. PAHO. Antibiotic resistance. WDC, USA. 2020. Last Accessed Date: 06.10.2021. Available from: https://www.paho.org/hq/index. php?option=com_docman\&tview=list\&tslug=resistencia-a-antimicrobianos5543\&tlemid=270\&llang=e

9. WHONET. Red de Vigilancia de la Resistencia a los Antimicrobianos WHONET-Argentina. Last Accessed Date: 06.10.2021. Available from: http:// antimicrobianos.com.ar/whonet-argentina/

10. ANLIS. Manuales de procedimiento INEI. Normas técnicas, 2007. Last Accessed Date: 06.10.2021. Available from: http://www.snvs.msal.gov.ar/ 
descargas/Manual\%20de\%20Normas\%20y\%20Procedimientos\%202007. pdf

11. WHO. Guidelines for ATC Classification and DDD assignment 2020. WHONIPH, 2020. Last Accessed Date: 10.02.2021. Available from: https://www. whocc.no/filearchive/publications/2020_ guidelines_web.pdf

12. ECDC. European Center for Disease Prevention and Control. Antibiotic consumption in the EU/EEA, Annual Epidemiological Report for 2018. Stockholm: ECDC; 2019.

13. European Antibiotic Resistance Surveillance Network (EARS-Net) reported an EU/EEA, 2017. Last Accessed Date: 10.02.2021. Available from: https:// www.ecdc.europa.eu/sites/portal/files/documents/AMR-surveillance-EARSNet-2017.pdf

14. WHO. WHO report on surveillance of antibiotic consumption: 2016-2018 early implementation. Geneva: World Health Organization; 2018. Licence: CC BY-NC-SA 3.0 IGO

15. Prestinaci $F$, Pezzotti $P$, Pantosti A. Antibiotic resistance: a global multifaceted phenomenon. Pathog Glob Health. 2015;109:309-18.

16. Austin DJ, Kristinsson KG, Anderson RM. The relationship between the volume of antibiotic consumption in human communities and the frequency of resistance. Proc Natl Acad Sci U S A. 1999;96:1152-6.
17. UN. At UN, global leaders commit to act on antibiotic resistance. Collective effort to address a challenge to health, food security, and development, 2016. Last Accessed Date: 10.02.2021. Available from: https://www.who. int/news/item/21-09-2016-at-un-global-leaders-commit-to-act-onantibiotic-resistance

18. Boni $S$, Marin $G$, Campaña $L$, Marin $L$, Corso A, Risso-Patron $S$, Gabriel $F$, Garay V, Limeres M. Disparities in antimicrobial consumption and resistance within a country: the case of beta-lactams in Argentina. Rev Panam Salud Publica. 2021;45:e76.

19. Global antibiotic resistance surveillance system (GLASS) report: early implementation 2020. Geneva: World Health Organization; 2020. Licence: CC BY-NC-SA 3.0 IGO.

20. Global WHO. Global Database for Antibiotic Resistance Country SelfAssessment (2018-2019). Last Accessed Date: November 2021. Available from: https://amrcountryprogress.org/8

21. Eurostat. Glossary: Official Country codes. Last Accessed Date: November 2021. Available from: https://ec.europa.eu/eurostat/statistics-explained/ index.php/Glossary:Country_codes 